\title{
Misconceptions and Realities of the 2011 Tunisian Election
}

\author{
Moez Hababou, United Bank of Switzerland, New York \\ Nawel Amrouche, Long Island University, New York
}

\section{ABSTRACT In response to the 2011 Tunisian elections and the uncertainty surrounding} Tunisia's future, we offer an empirical explanation of the election's results using socioeconomic and demographic variables. We aggregate many political analyses to describe the main parties and give insights into their strengths and weaknesses. We also examine common misconceptions advanced during the elections. Finally, we include a proposed electoral map that could be used by politicians to plan their future political strategies.

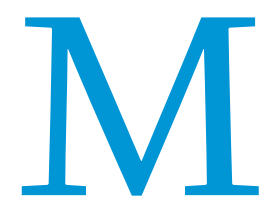

ohammed Bouazizi, a Tunisian street vendor, set himself aflame on December 17, 2010, and triggered an uprising that brought the 23-year rule (1987-2011) of Zine El Abidine Ben Ali to an end. This uprising sparked similar uprisings in other Arab countries in what has become commonly known as the "Arab Spring." On October 23, 2011, Tunisia became the first test of democracy for the Arab Spring by holding free and fair elections to elect members of its National Constituent Assembly (NCA) (Zelin 2011).

In this article, we introduce the key political parties in Tunisia that participated in the election. We attempt to debunk the main misconceptions about the election. We also provide an empirical explanation of the elections' outcome in Tunisia based on socioeconomic and demographic factors and propose an electoral map that could be used by political parties in future elections.

\section{THE MAIN POLITICAL PARTIES IN TUNISIA}

More than 100 political parties participated in the 2011 Tunisian elections. However, the major parties presented in this section enjoyed $72.1 \%$ of the popular vote and won $90.8 \%$ of the seats at the NCA (see Figure 1).

Ennahda was founded in 1981 as the Movement of the Islamic Tendency (Teyeb 2011) and was originally inspired by the Egyptian Muslim Brotherhood (Lewis 2011). Ennahda had a history of violence, but starting in the 1980 s it began to promote itself as

Moez Hababou is Director, Risk and Business Analytics at United Bank of Switzerland, New York. His professional experience spans various areas including risk management, market research, and quantitative modeling. He is a founding member of the Tunisian Network for a Successful Society (TUNESS). He can be reached at moez.hababou@ubs.com.

Nawel Amrouche is Associate Professor of Marketing at Long Island University, New York. She is affiliated with the Council of American Survey Research Organizations, and she is a founding member of the Tunisian Network for a Successful Society (TUNESS). She can be reached at naoual.amrouche@liu.edu. a moderate Islamist political party. It also served as the main opposition party to then-President Ben Ali (Wright 2001) until the latter eradicated Ennahda in the 1990 s by jailing and exiling many of its activists. The party is currently led by its cofounder Rachid Ghannouchi. Ghannouchi is a renowned scholar in Islamic thinking, and he has spent 20 years in exile before returning shortly after the revolution.

Ennahda was the big winner of the 2011 elections with $37.5 \%$ of the vote and $41 \%$ of the seats in the NCA. It has nationwide appeal across all governorates with a milder dominance in coastal governorates. A common theory is that Ennahda was successful at convincing voters that it is the best party for defending a Muslim and Arabic identity rather than a Europeanized identity (Alexander 2010). Ennahda also courted moderate voters by signaling its intent to preserve many of the modern and secular achievements that Tunisia had achieved, especially the Law of Personal Status, which significantly expanded women's rights. Consequently, Ennahda was labeled as a moderate Islamic party (Heneghan 2011).

The Congress for the Republic (CPR) was founded in 2001 by Moncef Marzouki (current Interim President of Tunisia). In 2002, then-President Ben Ali banned the CPR and forced Marzouki into exile in Paris (Farid 2011).

The CPR, which is a center-left secular political party, has established itself as the second leading political force in Tunisia thanks to its nationwide appeal. The party managed to gain seats across all governorates in the 2011 elections (Belkaid 2011). The CPR benefited from pursuing a centrist message and avoiding confrontation with Ennahda.

Ettakatol (The Democratic Forum for Labor and Liberties) is a secular center-leftist party that was founded in 1994 by Mustapha Ben Jafar (current Speaker of the NCA) and became official in 2002. ${ }^{1}$ The appeal of Ettakatol is concentrated in the north of the country and the governorate of Sfax. Like CPR, Ettakatol pursued a centrist message and avoided confrontation with Ennahda. This strategy allowed both CPR and Ettakatol to perform better than other 
Figure 1

Vote and Seat Distribution

\section{Seat Distribution}

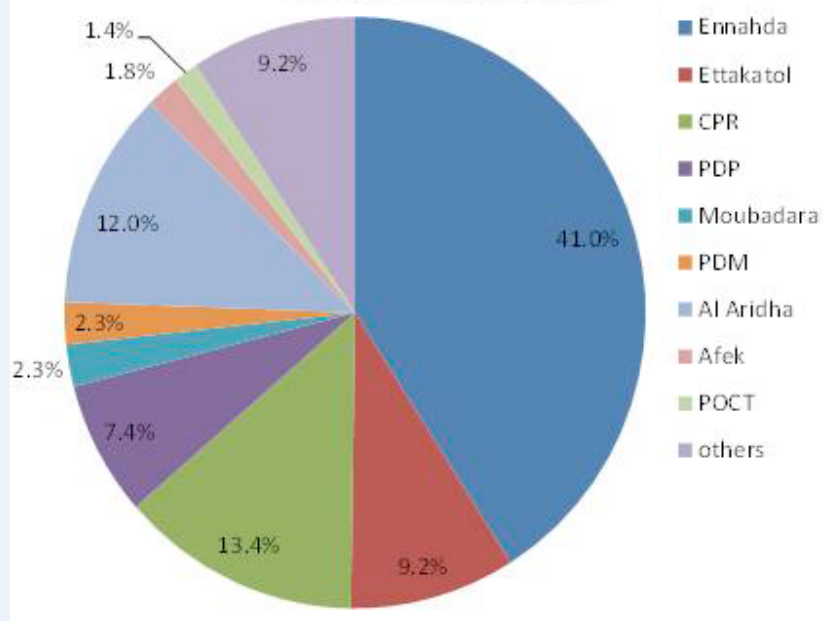

(Color online.)

secular parties (Alexander 2010). However, strong competition from Ennahda, CPR, and the Al Aridha party; the lack of a resonant message; and an ill-prepared structure in the interior governorates and the south of the country have limited Ettakatol's success.

Al Aridha (The Popular Petition for Freedom, Justice and Development) was formed after the revolution in March 2011. It was founded by Mohamed Hechmi Hamdi, owner of Al-Mustakillah Satellite TV (Ajmi 2011).

Al Aridha's popularity was the biggest surprise of the Tunisian election. Its popularity is higher in the interior governorates where the revolution actually started (Sidi Bouzid, Kasserine, Kairouan). Unlike other parties, Al Aridha focused primarily on economic and social reforms without addressing personal liberties, democracy, and the constitution. Questionable methods, such as the use of the Al-Mustakillah ${ }^{2}$ television network and support from officials previously affiliated with Ben Ali's Constitutional Democratic Rally (known by its French initials RCD), may have helped Al Aridha spread its message.

Progressive and Liberal Parties include the Pole Democrate Progessist (PDP), Afek Tounes, the Democratic Modernist Pole (PDM), the Moubadara Party, and the Tunisian Workers' Communist Party (PCOT).

The PDP was cofounded by Ahmed Nejib Chebbi (attorney and politician) and Maya Jribi (politician and active member in the Tunisian League of Human Rights) in 1983 as the Progressive Socialist Rally party and became official in 1988. Its name was changed to PDP in 2001 (Chrisafis 2011). The party is the most leftist secular party in Tunisia and is considered the fiercest opponent to Ennahda.

The PDP fell short of expectations because it did not achieve a position among the top three as many analysts had predicted (Coleman 2011; McCurdy 2011). Its weak performance in the capital city of Tunis was unexpected given the party's considerable media exposure and marketing efforts ${ }^{3}$ (Kefi 2011). This failure is the result of the PDP's electoral message that carried an extreme anti-Ennahda position. Therefore, many moderate voters expressed antipathy toward PDP's polarized politics (McCurdy 2011).

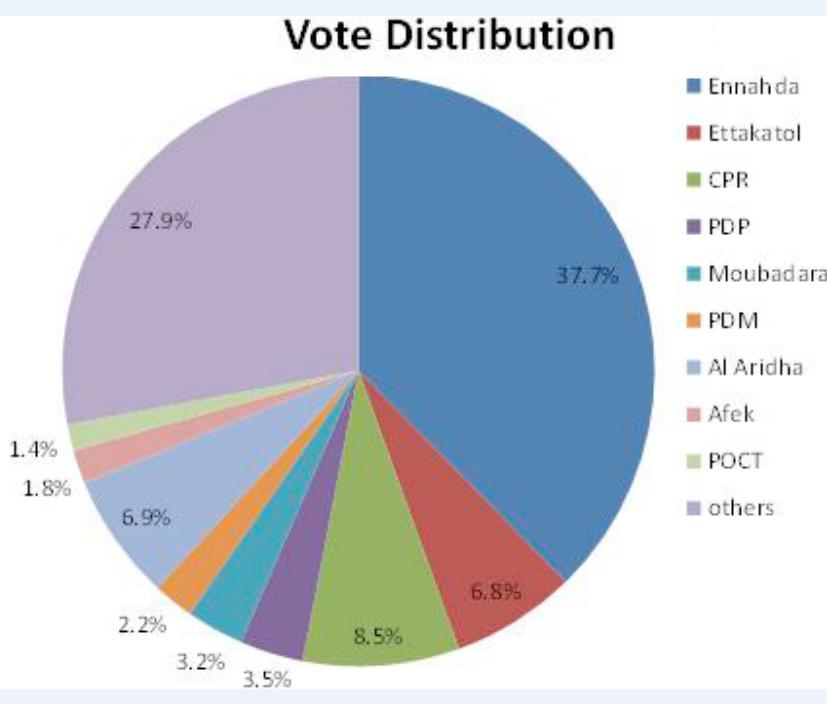

Afek Tounes is a center-right liberal party focusing on secularism and civil liberties founded after the revolution in March 2011. It mainly attracted intellectuals and the upper class (Chrisafis 2011).

PDM is a centrist-socialist coalition created to gain seats in the NCA. The party focuses on the separation between religion and politics and emphasizes the importance of gender equality. Together, Afek Tounes and PDM fared well mostly in coastal cities and around the capital.

The Moubadara Party, founded by Kamel Morjane (former Foreign Minister under Ben Ali regime), had a strong performance in the governorates of Monastir and Sousse because of the solid infrastructure of the RCD Party in those governorates (Sayah 2013).

The PCOT is a secular extreme left (Marxist-Leninist) political party formed in 1986. Despite being targeted by repressive practices of the Ben Ali regime (such as torture and jailing of its protesters), the PCOT was well known in Tunisia (Sta Ali 2011). Several famous leaders and political figures are part of its history including Hamma Hammami, a political activist noted for strong opposition to the government of Ben Ali, and the human rights lawyer Radhia Nasraoui. Its poor performance (less than $2 \%$ of the votes) can be explained by the global decline of communism and the party's lack of financial resources.

\section{DATA AND METHODOLOGY}

We collected our data from different sources, namely the Superior Independent Authority for the Elections-Tunisia (ISIE) (www .isie.tn), National Institute of Statistics-Tunisia (www.ins.nat.tn), Ministry of Industry and Trade-Tunisia (www.tunisieindustrie.nat.tn) and World Food Program (www.wfp.org). The data represent each of the 24 governorates and 27 electoral districts in Tunisia. ${ }^{4}$ The data include total votes and seats by party, macroeconomic variables for different sectors (e.g., education, transportation, tourism, telecommunication, and health) and some demographic variables (e.g., marital status, dwelling, and age range). The data representing macroeconomic and demographic variables were collected in 2007 and 2010. To avoid discrepancies 
Table 1

\section{Test of Difference of Average Votes for Male versus Female Candidates by Party}

\begin{tabular}{|c|c|c|c|c|c|c|}
\hline & \multicolumn{2}{|c|}{ MALE CANDIDATE } & \multicolumn{2}{|c|}{ FEMALE CANDIDATE } & \multirow[b]{2}{*}{ P-VALUE } & \multirow[b]{2}{*}{ T-STAT } \\
\hline & Observations & Average \% Vote & Observations & Average \% Vote & & \\
\hline Ennahda & 26 & 37.7 & 1 & 30.8 & NA & NA \\
\hline Moubadara & 15 & 3.88 & 3 & 1.72 & .24 & .59 \\
\hline PDM & 17 & 2.07 & 10 & 2.09 & .98 & -.02 \\
\hline PDP & 23 & 3.63 & 4 & 4.01 & 63 & -.48 \\
\hline РОСТ & 16 & 1.46 & 3 & 1.45 & .98 & .02 \\
\hline Ettakatol & 25 & 5.75 & 2 & 5.8 & .98 & -.01 \\
\hline Afek & 14 & 1.63 & 5 & 3.84 & .0049 & -3.23 \\
\hline CPR & 27 & & - & - & NA & NA \\
\hline
\end{tabular}

not wear a headscarf. This partially weakens our argument about the role of gender with respect to voting for Ennahda or $\mathrm{CPR}$, as gender bias could have been tactically built into the election results when preparing the candidates' list. However, our argument holds for some parties (Ettakatol, PDM, Afek, and PDP). In the end, women won 49 out of 217 seats, with 42 of those 49 seats belonging to Ennahda.

\section{Misconception 2: Too many parties confused the voters.}

Next we examine whether the multiplicity of parties caused

in the data, we normalized some variables with respect to the number of inhabitants (e.g., number of hotels and number of libraries) and others with respect to the area by governorate (e.g., national roads and cultivated areas).

We note several limitations to this study, including the small sample size, the lack of exit polls, and the limited availability of socioeconomic and demographic data. Another limitation is the difficulty of analyzing the vote of the Tunisian diaspora namely in North America, France, Germany, Canada, Italy, and the Middle East.

\section{COMMON MISCONCEPTIONS ABOUT THE TUNISIAN ELECTIONS}

In this section, we analyze some common misconceptions regarding the Tunisian elections. These misconceptions were widely circulated by political analysts, journalists, and Tunisian people.

\section{Misconception 1: Voters are more likely to vote for men.}

Despite efforts to promote the participation of female candidates in the election and the enactment of the alternation principle imposed by the ISIE, the percentage of women who head electoral lists remained low at $7 \% .^{5}$ This alternation principle stated that in the electoral lists across all regions, male and female candidates must alternate, so that every electoral list is equally divided between men and women. Knowing that conservatism still prevails in many governorates, one may assume that voters may favor male candidates.

As shown in table 1, we do not see any discernible difference between the votes for electoral lists headed by women as compared with those headed by men, suggesting there is no negative bias against women candidates. We may then infer that voters make their selection based on parties rather than on candidates. However, the balanced distribution of the head on the electoral lists was actually uneven because coastal governorates (supposedly more liberal) had a higher percentage of candidate lists headed by women ( $17 \%$ for coastal governorates vs. $9 \%$ for interior governorates). In addition, the more conservative parties strategically picked the woman who would head their lists. For instance, the only woman to head the electoral list for Ennahda was Souad Abderrahim, who was a candidate in Tunis II, the most liberal governorate. She was also the only Ennahda candidate who does vote dilution. The data show that the highest percentages of wasted votes occurred in governorates that had fewer parties running in the elections (mostly in the south and interior). In fact, a negative correlation ( -0.32 ; $p$-value 0.002$)$ exists between the number of electoral lists and the percentage of wasted votes. A striking case is that the electoral districts of Tunis I and Tunis II (two electoral districts of the capital city of Tunis), each with nearly 80 parties running in the elections (see figure 2), had the lowest percentages of wasted votes $(23 \%)$. This result may be because of the intense media focus on voting for parties with bigger chance of winning a seat at the NCA, a better understanding of electoral rules, and stronger name recognition of leading parties in the coastal governorates.

\section{Misconception 3: Liberal parties lost the most because of the plurality of the votes.}

A common misconception is that progressive parties would have done better if there had been less vote dilution. By comparing the pie charts of seats assigned to each party and the votes' distribution (see figure 1), we see that CPR, Ettakatol, PDP, and Al Aridha gained substantially higher percentages of seats compared to their share of the votes. For instance, CPR and Ettakatol received 8.5\% and $6.8 \%$ of the vote, respectively, while being awarded $13.4 \%$ and $9.2 \%$ of the seats at the NCA. The PDP was awarded $7.4 \%$ of the seats at the NCA, which is more than twice its share (3.5\%) of the votes (see figure 1). The biggest losers were smaller parties and independent lists.

\section{Misconception 4: It pays to focus on winning in Tunis.}

A primary cause of the 2011 revolution was widespread discontent about economic conditions in governorates largely ignored by the Ben Ali regime. Prior to the 2011 uprising, similar protests took place in southern and internal governorates such as Redeyef 2009 and Gafsa 2008 (Hopmann and Zartman 2012). Hence, the ISIE proposed an electoral system that provides a greater voice to these neglected governorates (see figure 3). Under this system, gaining a seat in the NCA requires nearly twice as many votes in the major cities (e.g., Tunis and Sousse) as it does in the internal governorates (e.g., Tatouine and Tozeur). This situation led some leading parties to compete in crowded coastal governorates even though winning votes in interior governorates would have 
Figure 2

Percent Votes Wasted versus Number of Electoral Lists by Governorate

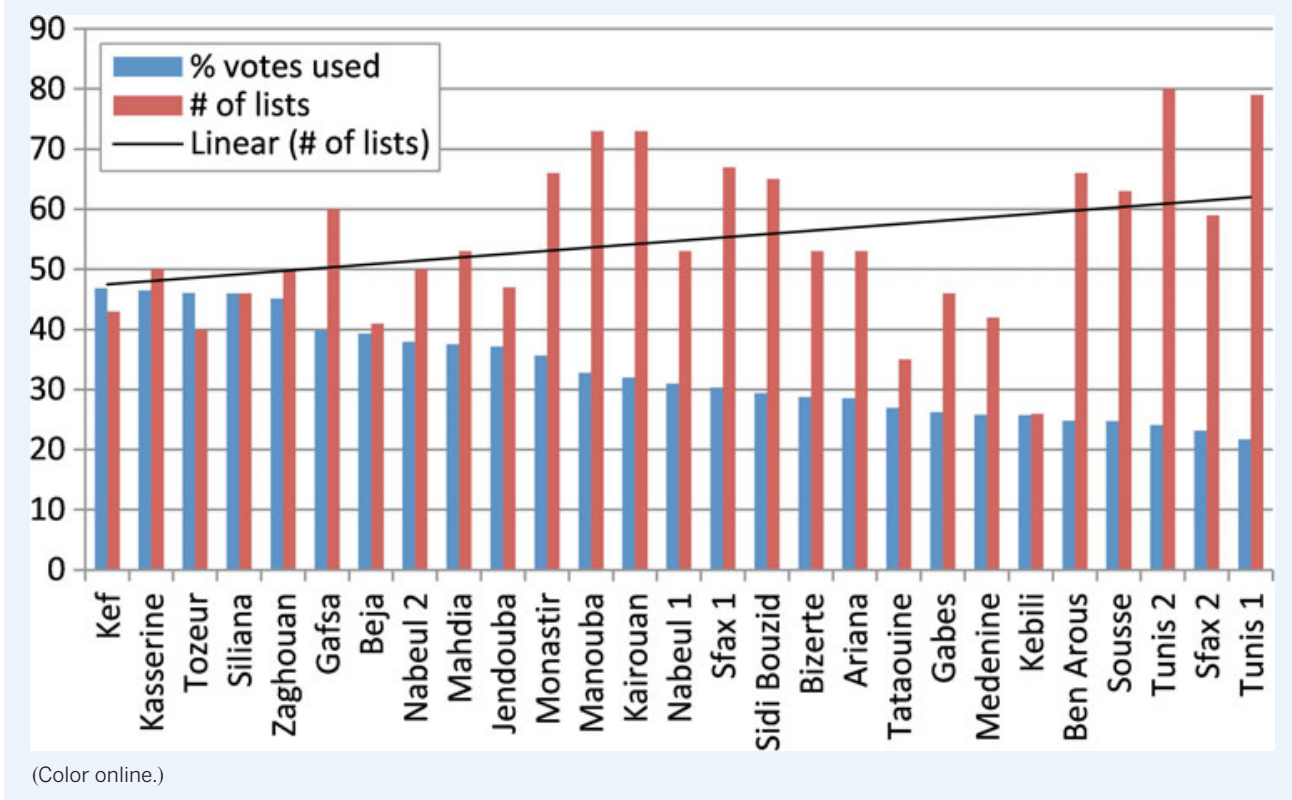

Figure 3

Number of Voters Required per Seat

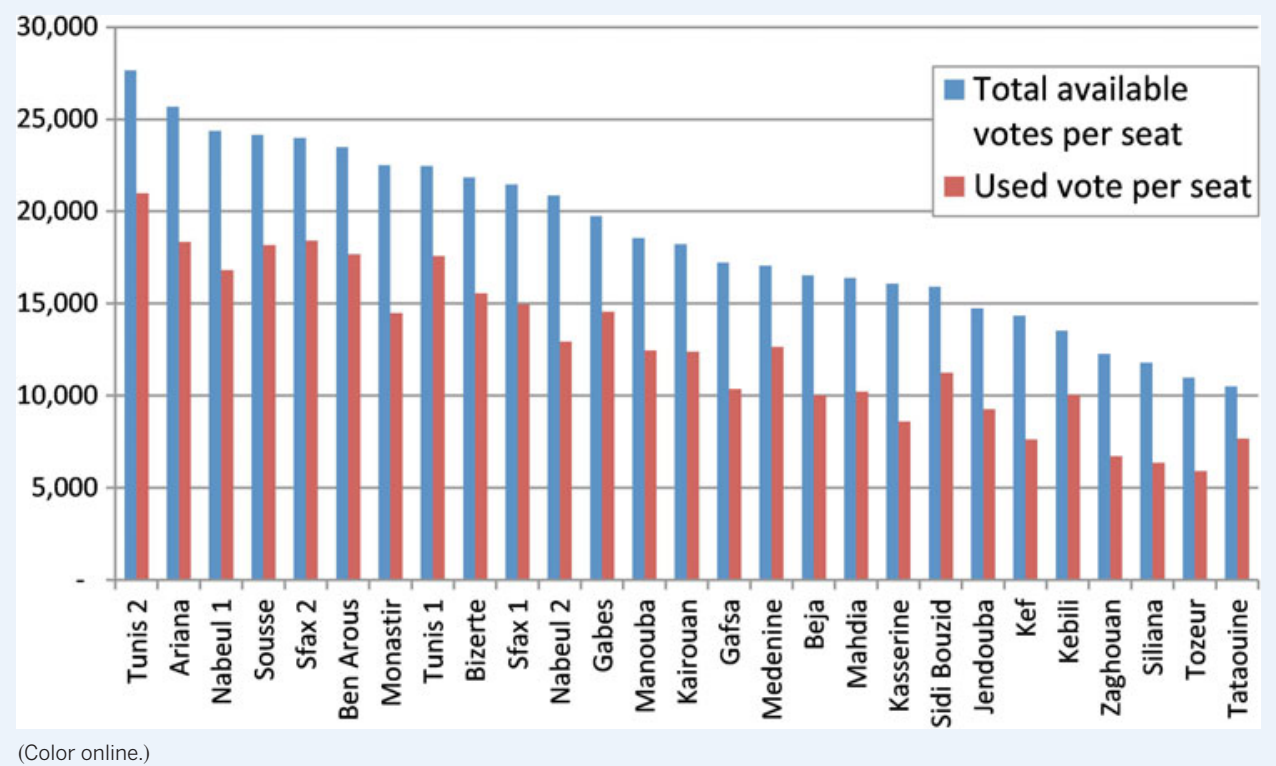

We analyzed whether main parties would benefit if progressive parties (PDP, PDM, and Afek) merged and formed a coalition. We simulated the election results assuming that the coalition was formed prior to the election. The results are a direct implication of the ISIE seat assignments. Overall, there would have been a net gain of only two seats for the coalition. However, most gains would have been realized in interior governorates (e.g., Gabes, Kairouan, Kebili, Kef, and Tozeur) where progressive parties did not do well. The coalition strategy would not have been favorable, however, in governorates where progressive parties performed better (Tunis I, Nabeul I, Ben Arous, and Ariana). In fact, Ennahda would have profited as much as the progressive coalition by gaining two additional seats. The only meaningful benefit would have been that the resulting coalition would become the second largest political party in Tunisia ahead of the CPR (see table 2).

\section{SOCIOECONOMIC AND DEMOGRAPHIC DRIVERS}

Next, we attempted to uncover the socioeconomic and demographic determinants that influenced each party's votes. There are many approaches to this as suggested by Al-Tayeb (2012): (1) a sociological model measuring the impact of socioeconomic drivers on voters' choice, (2) a psychopolitical model proposing that voters choose candidates out of an emotional and sentimental relationship, and (3) an economic

provided a higher payoff in terms of gaining seats in the NCA. For instance, the electoral district of Tunis II was overloaded with high-profile candidates (e.g., Ahmed Nejib Chebbi (PDP) and Ahmed Brahim (PDM)), resulting in many of them not being elected or barely winning seats in the NCA.

\section{Misconception 5: It pays to form electoral coalitions.}

In February 2012, three opposition parties (Afek, PDP, and Republican Party) announced plans to merge into a single leftist party, ${ }^{6}$ and this news was cheered by modernists as this merger creates force. But is this merger better than acting independently? model assuming that voters are rational in drawing their political choices given degrees of benefits. We followed the first approach and used regression models where the share of votes for each party is the dependent variable and various socioeconomic and demographic factors are the independent variables (see table 3 ).

\section{Factors Affecting Ennahda Vote}

This model has an R-squared of $80.9 \%$. The following variables had a negative impact on the share of votes Ennahda received: the percentage of agricultural land, the number of hotels, and the percentage of families receiving public assistance. The number of 
Table 2

\section{Impact of Progressive Coalition on Seats' Allocation}

\begin{tabular}{lccl} 
GOVERNORATES & $\begin{array}{c}\text { TOTAL } \\
\text { SEATS }\end{array}$ & $\begin{array}{c}\text { NET CHANGE } \\
\text { FOR COALITION }\end{array}$ & $\begin{array}{c}\text { NET CHANGE FOR } \\
\text { OTHER PARTIES }\end{array}$ \\
\hline Gabes & 7 & +1 seat & Al Aridha -1 \\
\hline Kairouan & 9 & +1 seat & Ettakatol -1 \\
\hline Kebili & 5 & +1 seat & Al Aridha -1 \\
\hline Kef & 6 & +1 seat & Ettakatol -1 \\
\hline Manouba & 7 & +1 seat & Al Aridha -1 \\
\hline Monastir & 9 & +1 seat & Al Aridha -1 \\
\hline Sfax II & 9 & +1 seat & POCT -1 \\
\hline Tozeur & 4 & +1 seat & CPR -1 \\
\hline Ariana & 8 & -1 seat & Al Aridha +1 \\
\hline Ben Arous & 10 & -1 seat & Ennahda +1 \\
\hline Medenine & 9 & -1 seat & Independents +1 \\
\hline Nabeul I & 7 & -1 seat & Ennahda +1 \\
\hline Sidi Bouzid & 8 & -1 seat & Independents +1 \\
\hline Tunis I & 9 & -1 seat & Al Aridha +1 \\
\hline & & &
\end{tabular}

pharmacies and the total kilometers of national roads positively influenced the votes. The result shows that not only poor, rural governorates voted for Ennahda, but urban governorates did as well. The negative impact of agricultural land is probably because of Ennahda's presence in the semidesert of south Tunisia.

\section{Factors Affecting Ettakatol Vote}

The model explains 90\% of Ettakatol's votes and shows that higher demographic density-and older and wealthier population (using number of cars as a proxy)-and proximity to the capital had a positive effect on Ettakatol's share of the vote. These results are consistent with the characteristics of Ettakatol's supporters.

\section{Factors Affecting CPR Vote}

This model has an R-squared of $61.4 \%$ and highlights the strength of an economic rationale. The governorates that voted for CPR are characterized by higher education at a lower age, higher industrial level, and higher level of availability of free health care for families. However, the number of libraries and the level of access to safe drinking water had a negative impact on CPR's share of the vote.

\section{Factors Affecting Al Aridha Vote}

This model explains 55.3\% of the $\mathrm{Al}$ Aridha vote. The agricultural level of the governorate, the household size, the lower level of education for young adults (aged 19-24), and the unemployment

Table 3

Key Influences of Main Parties' Vote

\begin{tabular}{|c|c|c|c|c|c|c|c|c|c|c|}
\hline & \multicolumn{2}{|c|}{ ENNAHDA } & \multicolumn{2}{|c|}{ ETTAKATOL } & \multicolumn{2}{|c|}{ CPR } & \multicolumn{2}{|c|}{ AL ARIDHA } & \multicolumn{2}{|c|}{ PROGRESSIVE } \\
\hline R2 & \multicolumn{2}{|c|}{0.809} & \multicolumn{2}{|c|}{0.90} & \multicolumn{2}{|c|}{0.614} & \multicolumn{2}{|c|}{0.553} & \multicolumn{2}{|c|}{0.515} \\
\hline R2 adjusted & \multicolumn{2}{|c|}{0.756} & \multicolumn{2}{|c|}{0.879} & \multicolumn{2}{|c|}{0.507} & \multicolumn{2}{|c|}{0.459} & \multicolumn{2}{|c|}{0.413} \\
\hline \multirow[t]{2}{*}{ Sig. F. } & \multicolumn{2}{|c|}{0.000} & \multicolumn{2}{|c|}{0.000} & \multicolumn{2}{|c|}{0.002} & \multicolumn{2}{|c|}{0.003} & \multicolumn{2}{|c|}{0.006} \\
\hline & $\begin{array}{l}\text { Impact } \\
\text { Power }\end{array}$ & $\begin{array}{c}\text { Impact } \\
\text { Direction }\end{array}$ & $\begin{array}{l}\text { Impact } \\
\text { Power }\end{array}$ & $\begin{array}{c}\text { Impact } \\
\text { Direction }\end{array}$ & $\begin{array}{l}\text { Impact } \\
\text { Power }\end{array}$ & $\begin{array}{c}\text { Impact } \\
\text { Direction }\end{array}$ & $\begin{array}{l}\text { Impact } \\
\text { Power }\end{array}$ & $\begin{array}{c}\text { Impact } \\
\text { Direction }\end{array}$ & $\begin{array}{l}\text { Impact } \\
\text { Power }\end{array}$ & $\begin{array}{c}\text { Impact } \\
\text { Direction }\end{array}$ \\
\hline Agricultural land & 1 & - & & & & & 1 & + & & \\
\hline Pharmacies & 2 & + & & & & & & & & \\
\hline Hotels & 4 & - & & & & & & & 4 & + \\
\hline National roads & 3 & + & & & & & & & & \\
\hline Health-care access & 5 & - & & & & & & & & \\
\hline Demographic density & & & 1 & + & & & & & & \\
\hline Distance to capital & & & 3 & - & & & & & 3 & - \\
\hline Number of cars & & & 4 & + & & & & & & \\
\hline Age 40 and above & & & 2 & + & & & & & & \\
\hline Access to drinking water & & & & & 4 & - & & & & \\
\hline Education age 6 to 14 & & & & & 1 & + & & & 1 & + \\
\hline Libraries & & & & & 2 & - & & & & \\
\hline Industrial zones* & & & & & 5 & + & & & & \\
\hline Free health care & & & & & 3 & + & & & & \\
\hline Education age 19 to 24 & & & & & & & 4 & - & & \\
\hline Unemployment age 30 to 34 & & & & & & & 3 & + & & \\
\hline Household size & & & & & & & 2 & + & & \\
\hline Age 15 to 40 & & & & & & & & & 2 & - \\
\hline
\end{tabular}

*The Industrial Land Agency established the number of industrial zones. 
rate of those aged $30-34$ had a positive impact on Al Aridha's share of the vote. In other words, poverty, illiteracy, and economic factors explain the surprisingly high share of vote for Al Aridha.

\section{Factors Affecting Progressive Vote}

The model explains $51.5 \%$ of progressive parties' votes (Afek, PDP, and PDM). These parties' key voters are educated, wealthy, and older. Another key influence is the distance to the capital as these parties are much more popular in Tunis.

\section{THE TUNISIAN ELECTORAL MAP}

Finally, we present a strategic electoral map of Tunisia that could be used in the next elections (see figure 4). We explore which governorates have similar characteristics and could be grouped together as a voting block that would vote for the same parties. We used the k-mean clustering analysis and included the votes' share by party as input data. We find that governorates are grouped along five main clusters (see table 4):

\section{Cluster 1 Represents "the Ennahda Stronghold"}

Cluster 1 is comprised of the governorates of Gabes, Kairouan, Medenine, and Tatouine, where Ennahdahad the strongest showing. The Ennahda vote also has a strongidentity connotation as these governorates have always been characterized by deeper conservative Islamic values and Arab nationalism. Moreover, many Ennahda key political figures are native to the south.

\section{Cluster 2 Represents "the Al Aridha Fortress"}

Cluster 2 is solely comprised of Sidi Bouzid, where the revolution began. Sidi Bouzid has the lowest literacy and demographic growth rates in Tunisia and a high unemployment rate.

\section{Cluster 3 Represents "the Dostourian Vote"}

Cluster 3 consists of the governorates of Monastir and Sousse and is characterized by a strong showing of the Dostourian parties (mainly El Moubadara). ${ }^{7}$

\section{Cluster 4 Captures "the Progressive-Liberal Vote"}

Cluster 4 consists of the coastal governorates of Ariana, Ben Arous, Bizerte, Manouba, Nabeul, Sfax, and Tunis, as well as the interior governorate of Kebili. The presence of Kebili in this cluster is probably because of the strong performance of CPR in this governorate (27\% of the vote). The centrist and liberal parties (Afek, PDP, Ettakatol, and PDM) had their best showing here as well. These governorates have a higher urban density and demographic growth rate, lower unemployment and illiteracy rates, better indicators of wealth (e.g., cars per inhabitants, doctors per inhabitants), and higher levels of education.

\section{Cluster 5 Embodies "the Economic Vote"}

Cluster 5 consists of the northwestern governorates (Beja, Kef, Siliana, and Jendouba) and the interior southwestern governor-

\section{Figure 4}

\section{The Tunisian Electoral Map}

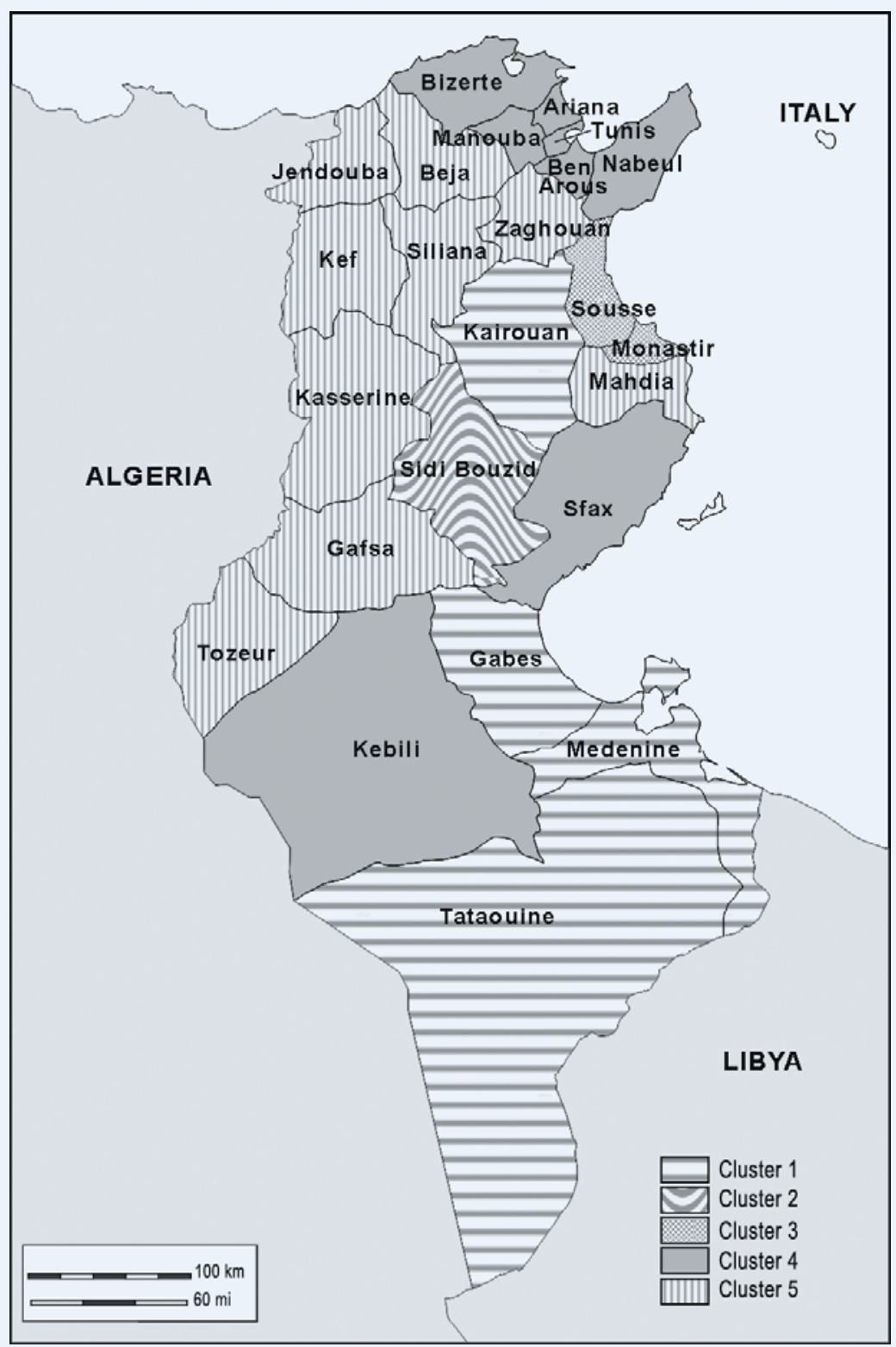

Prepared by Sana Karray Hababou ates (Tozeur, Kasserine, and Gafsa), as well as Mahdia and Zaghouan. These governorates, mostly geographically contiguous, are characterized by slower economic growth, low demographic density, high rates of migration, and the highest unemployment rates. Voters in these governorates seem mostly concerned about poor economic conditions and are not driven by ideological preferences.

\section{CONCLUSION}

This study provides an empirical analysis of the 2011 Tunisian elections and offers insights on misconceptions that have circulated since the elections. The regression analysis identifies potential influences of the vote. Political parties could use this information to enhance future campaign strategies. Finally, our findings offer five voting clusters that represent a new Tunisian electoral map. This 
Table 4

Profile of the Tunisian Electoral Map

\begin{tabular}{|l|l|l|l|l|} 
CLUSTER 1 & CLUSTER 2 & CLUSTER 3 & CLUSTER 4 & CLUSTER 5
\end{tabular}

\begin{tabular}{|c|c|c|c|c|c|}
\hline \multirow[b]{2}{*}{ NUMBER OF GOVERNORATES } & & & & & \\
\hline & 4 & 1 & 2 & 9 & 8 \\
\hline Ennahda (\% vote) & 50.77 & 15.58 & 34.15 & 32.83 & 40.08 \\
\hline Ettakatol (\% vote) & 1.91 & 1.05 & 4.02 & 4.03 & 9.10 \\
\hline CPR (\% vote) & 6.94 & 1.69 & 4.85 & 6.00 & 12.35 \\
\hline PDP (\% vote) & 3.22 & 1.18 & 2.68 & 4.71 & 3.63 \\
\hline Moubadara (\% vote) & 0.21 & 1.22 & 19.78 & 1.14 & 0.96 \\
\hline PDM (\% vote) & 1.25 & 0.89 & 1.98 & 2.11 & 2.43 \\
\hline Al Aridha (\% vote) & 8.38 & 38.20 & 4.18 & 7.90 & 4.25 \\
\hline Afek (\% vote) & 1.86 & 0.50 & 1.85 & 0.91 & 1.88 \\
\hline РОСТ (\% vote) & 0.90 & 1.31 & 1.00 & 1.87 & 1.56 \\
\hline Progressive (\% vote) & 6.32 & 2.58 & 6.51 & 7.74 & 7.94 \\
\hline Other parties/Independents ( $\%$ vote) & 24.56 & 38.36 & 25.50 & 38.49 & 23.75 \\
\hline Demographic density & 46.00 & 55.60 & 344.50 & 69.85 & 721.26 \\
\hline Demographic growth & 0.73 & 0.48 & 2.35 & 0.76 & 1.82 \\
\hline Urbanization & 59.90 & 25.44 & 90.00 & 47.34 & 74.89 \\
\hline Percent cultivated land & 41.23 & 93.60 & 80.51 & 53.27 & 47.75 \\
\hline Number of inhabitant per doctor & 1,665 & 1,877 & 1,114 & 1,677 & 1,166 \\
\hline$\%$ Access to drinking water & 70.28 & 100.00 & 87.45 & 82.27 & 81.05 \\
\hline$\%$ Population with a landline & 0.19 & 0.03 & 0.28 & 0.13 & 0.17 \\
\hline Percent households with cars & 22.43 & 15.00 & 23.25 & 12.94 & 24.39 \\
\hline Percent unemployment & 14.05 & 14.10 & 9.15 & 18.50 & 12.93 \\
\hline$\%$ Population age 15 to 40 & 43.75 & 43.60 & 45.15 & 42.98 & 45.16 \\
\hline$\%$ Population age 40 plus & 26.70 & 25.90 & 26.95 & 29.21 & 29.86 \\
\hline$\%$ Married & 50.38 & 49.00 & 52.55 & 51.07 & 52.14 \\
\hline Average household size & 5.05 & 5.15 & 4.44 & 4.73 & 4.45 \\
\hline$\%$ Illiterate (age 10 plus) & 20.53 & 28.26 & 13.87 & 24.56 & 15.92 \\
\hline \% People in School age 19 to 24 & 13.13 & 10.50 & 22.80 & 12.48 & 20.96 \\
\hline
\end{tabular}

map can serve as an important tool for political parties in planning their campaign strategies for the next elections.

\section{ACKNOWLEDGMENTS}

We thank the reviewers and Sabrina Su for their valuable comments to improve the paper. We also thank Sana Karray Hababou for her help in creating the electoral map.

\section{NOTES}

1. www.ettakatol.org.

2. According to the electoral code, political parties were forbidden from using foreign TV channels to carry out their political message. Given that AlMustakillah (www.almustakillah.com) is based in London, UK, it should have not been allowed to promote Al Aridha.

3. Although no exact estimates on total spending by party are available, it is widely documented that the PDP and Union Patriotique Libre (UPL) parties spent the most during the elections.

4. There are more specifically 24 governorates and 27 electoral districts because three governorates (Nabeul, Tunis, and Sfax) have each 2 sub-governorates (e.g., Tunis I and Tunis II). However, for the purpose of our statistical analysis we aggregate the votes for sub-governorates and consider only the governorates because socioeconomic and demographic variables are available only for the 24 governorates and not for sub-governorates.
5. For more details, see ISIE website: www.isie.tn.

6. http://www.tap.info.tn.

7. These two regions mark the birth place of the Dostourian movement, which was at the forefront for Tunisia's fight for independence from French colonialism and included historic leaders such as Habib Bourguiba, Farhat Hached, and Bahi Ladgham.

\section{REFERENCES}

Ajmi, Sana. 2011. "People's Petition for Freedom, Justice and Development." http://www.tunisia-live.net.

Alexander, Christopher. 2010. Tunisia: Stability and Reform in the Modern Maghreb. London and New York: Routledge-Taylor \& Francis.

Al-Tayeb, Aisha. 2012. "A Reading into the Meaning and Significance of Tunisia's Election Results.” Arab Center for Research \& Policy Stud ies. Doha case analysis. February 2012.

Belkaid, Akram. 2011. "Tunisie: Les Enseignements du Scrutin." http:// www.slateafrique.com/61395 /tunisie-enseignements-du-scrutinEnnahda.

Chrisafis, Angelique. 2011. "Tunisian Elections: The Key Parties.” http:// www.guardian.co.uk/world/2011/oct /19/tunisia-elections-the-keyparties.

Coleman, Isobel. 2011. "Tunisia's Upcoming Elections: Part II." http:// www.isobelcoleman.com/2011 /10/21/tunisias-upcoming-elections -part-ii/.

Farid, Sonia. 2011. "Moncef Marzouki Declares Presidential Candidacy." Al Arabiya News.

Heneghan, Tom. 2011. "Analysis: Ennahda's Reformist Tunisian Islamism Has Strong Roots." http:// uk.reuters.com/article/2011/11/o7 /uk-tunisia-islamism-reform -idUKTRE7A64BI20111107.
Hopmann, P. Terrence, and William I. Zartman. 2012. "Tunisia: Understanding Conflict 2012.” Washington, DC: Johns Hopkins University, SAIS.

Kefi, Ridha. 2011. “Tunisie: Les Premieres Lecons d'un Scrutin Historique.” http:// www.kapitalis.com/politique/national/6494-tunisie-les-premieres-lecons-dun -scrutin-historique.html.

Lewis, Aidan. 2011. "Profile: Tunisia's Ennahda Party." http://www.bbc.co.uk/news /world-africa-15442859.

McCurdy, Daphne. 2011. "A Guide to the Tunisian Elections 2011." Project on Middle East Democracy.

Sayah, M. Habib. 2013. "What the New Destourian Front Means for Tunisia." http://fikraforum.org/?p=3254.

Sta Ali, H. 2011. "Tunisian Workers Communist Party”. http://www.tunisia -live.net/2011/o9/26/party-profile-tunisian-workers-communist-party-parti -communiste-des-ouvriers-de-tunisie.

Teyeb, Mourad. 2011. "What Role for the Islamists?" Al-Ahram Weekly. January 27, 2011.

Wright, Robin. 2001. Sacred Rage, The Wrath of Militant Islam. New York: Simon and Schuster Inc.

Zelin, Aaron Y. 2011. “The Arab Spring's First Real Test of Democracy Arrives in Tunisia." http://www.foreignaffairs.com/articles/136605/aaron-y-zelin/the-arab -springs-first-real-test-of-democracy-arrives-in-tunisia. 